In order to utilize these objectives in an optimal way, it is of importance to obtain knowledge about the necessary crossbreeding parameters. In many cases, females of the extraneous breed are not available in the country considered. This makes it difficult to obtain estimates of the needed crossbreeding parameters. By utilizing a modern AI breeding program, however, an experiment can be planned in such a way that crossbreeding parameters of interest can be estimated. The experimental plan necessitates the following steps :

I. Selection of bulls within extraneous populations according to their proves.

2. Importation of semen from the selected bulls.

3. The imported semen doses are inseminated on elite cows in the native breeding population.

4. Young bulls of $F_{1}$ are progeny tested.

5. Young bulls of three-quarter of the extraneous breed are produced by inseminating unselected $F_{1}$-daughters with the imported semen.

6. Young bulls of three-quarter of the extraneous breed are progeny tested.

7. The regular AI breeding programme of the native breeding population yields groups of control.

By utilizing production records of cows with different proportion of the extraneous breed, the data can be used to estimate the following parameters :

I. The difference between the imported bulls of the extraneous breed and the contemporary native elite bulls in general combining ability.

2. The magnitude of the heterotic effect.

Thus, the crossbreeding parameters of actual interest for the native breeding population can be estimated.

\title{
VORLÄUFIGE ERGEBNISSE AUS DER KREUZUNG VON ROTBUNTEN HOLSTEIN-FRIESIAN MIT FLECKVIEH IN BAYERN
}

G. Averdunk, A. GotTschalk, H. KRäusslich, E. Schwarz. - Bayerische Landesanstalt f. Tierzucht, 8011 Grub b. München (BRD).

Ưber vorläufige Ergebnisse der Leistungen der Kreuzungen von Rotbunten Holstein-Friesian Bullen und Fleckviehkihen wird berichtet. In der I. Laktation zeigten die $F_{1}$-Tiere im Vergleich zu reinrassigen Fleckvieh-Stallgefährtinnen eine Differenz von $+700 \mathrm{~kg}$ Milch, $+25 \mathrm{~kg}$ Fett und - o,05 Prozent Fett. Die gewogene Differenz nach dem Contemporary Comparison war mit + $594 \mathrm{~kg} \mathrm{Milch},+20 \mathrm{~kg}$ Fett und - 0.08 Prozent Fett etwas geringer. Das Erstekalbealter der $\mathrm{F}_{1}$-Tiere war um I.8 Monate niedriger, während die Melkbarkeit, Euterform und Körpergrösse deutlich höher lagen. Die Konformation der Kühe und Bullen war im Hinblick auf die Fleischproduktion negativ beeinflusst.

Die Ergebnisse der Fleischleistungsprüfung an 2 Stationen zeigten bei den $F_{1}$-Bullen eine grössere Frühreife wie bei den Flechviehvergleichsbullen. Bei der Mastprüfung bis zum 50o. Lebenstag hatten die $F_{1}$-Bullen ein um $I_{3} \mathbf{~ k g}$ geringeres Gewicht bzw. ein Unterschied von $34 \mathrm{~g}$ Zunahme im Prüfungsabschnitt vom I I2. - 500. Tag. Auf höherem Zunahmeniveau betrug die Differenz in der Zunahme $67 \mathrm{~g}$. Die $F_{1}$-Schlachtkörper hatten mehr Beckenhöhlen- und Nierenfett (1.4 kg), einen geringeren Pistolenanteil (1.2 Prozent eine geringere Rückenmuskelfläche $\left(8.7 \mathrm{~cm}^{2}\right.$ an 8./9. Rippe) und eine grössere Schlachtkörperlänge $(1.9 \mathrm{~cm})$. Die Schlachtkörper waren auf dem Schlachtviehmarkt weniger akzeptabel und wurden teilweise diskriminiert.

Der relative Anteil von Heterosis an den Leistungsunterschieden der $F_{1}$-Tiere kann zum gegenwärtigen Stand des Versuches noch nicht beurteilt werden.

\section{A SCHEME FOR COMPARISON}

\section{OF DIFFERENT STRAINS OF FRIESIANS}

\section{H. SkJervold. - The Agricultural University of Norway, Aas-NLH, Norway.}

During the last decades large effort has been made in developing efficient breeding schemes in various populations in dairy cattle.

An important part of such breeding schemes is a continuous measuring of achieved genetic 
change in the population. A fairly accurate estimate of the rate of genetic improvement is of course of importance in the further planning of the testing and selecting schemes.

In practice, however, we may have had a large quality difference between various foundation stocks. In AI-breeding therefore we in addition of measuring genetic gain also want to make comparisons with other actual populations.

In the following I will briefly describe the comparison with other breeds which are going on in connection with the AI-breeding in Norway.

Because of our rather liberal breed policy, it is in artificial insemination possible to make breed comparisons by use of semen from other populations.

In $197^{\circ}$ we decided to make a comparison between our dairy cattle populations and three strains of Friesian, namely strains of Holstein-Friesian from Canada, U. S. A. and Great Britain.

For this experiment we imported semen of selected bull sires from each of these Friesian populations. The selection was based entirely on progeny testing results (expected breeding value for fat corrected milk).

Because of a rather expensive quarantine procedure, the semen importation was made only once. We imported semen from 6 selected bulls from U.S. A., 5 from Canada and 6 from Great Britain.

The scheme for this comparison of different populations of dairy cattle is as follows :

- Based on the cow index a group of potential bull-dams were selected for insemination with imported semen. A careful evaluation has been made in order to get as equal quality as possible for the different groups of dams.

- Semen from each of these $I_{7}$ bulls is used for insemination of 60 elite cows during three mating seasons, namely $1972 / 73,1973 / 74$ and $1974 / 75$.

- Each year 5-6 young sons of each of the Friesian bulls are put into a performance testing procedure, together with about 250 bull-calves from the ordinary planned matings.

- Based on the performance testing 2-3 sons of each Friesian bull are selected for use in AI together with about iro bulls from the ordinary intake of young bulls.

- The half-breed bulls will, as the other bulls, immediately be used for inseminations of about 2 thousand cows as a basis for progeny testing. Further we, of course, are storing a quantity of frozen semen.

- If any of the half-breed are among the best progeny tested bulls, they will be selected as bull sires for production of the next batch of AI-bulls.

About I20 sons of these selected Friesian bulls are expected to be progeny tested during a period of three years. The average size of the progeny groups is expected to be about I 50 daughters.

These half-breed bulls will be compared with a large number of sons from 3 batches of our own bull sires. They will also be compared with a limited number of sons of Swedish bull sires ( $\left.{ }^{1}\right)$.

These comparisons therefore comprise following 6 populations :

Holstein Friesian from Canada
Holstein Friesian from U. S. A.
British Friesian
Swedish Friesian
Swedish Red and White (S. R. B.)
Norwegian Red Cattle (N. R. F.).

The results from the first batch of performance testing we get this year. This year we also get informations about the milk yield in the first lactation for some 30 daughters born in the quarantine station.

During the following years we expect a large quantity of informations from these comparisons. However, we have to wait until $1977 / 78$ before we get the first large batch of progeny tested bulls from these three strains of Friesian.

By comparison of groups of crossbreed with different proportions of the extraneous breed, it would also be possible to estimate the actual heterosis effect (FrmLAND, I974).

By means of this experiment it will be possible to compare the quality of our dairy cattle population with five of the most interesting populations concerning import of genes.

If any of the "imported "bull sires prove to be significant better than ours, of course we should use such bulls. If, in contrary, the "imported " bull sires do not prove to be as good as the best amolig the "native", we have by this comparison got important informations for use in further planning of AI-breeding in dairy cattle.

(1) Since I967 we have had a regular exchange of semen from bull sires in Sweden. 